\title{
Magnesium permeation through mechanosensitive channels: single-current measurements
}

\author{
Alexander V Staruschenko ${ }^{1,2, *}$, Anastasiya V Sudarikova ${ }^{1, *}$, Yuri A Negulyaev ${ }^{1}$, Elena A Morachevskaya ${ }^{1}$ \\ ${ }^{1}$ Institute of Cytology, Russian Academy of Sciences, Tikhoretsky Ave., 4, St Petersburg 194064, Russia, ${ }^{2}$ Department of Physiology, \\ University of Texas Health Science Center at San Antonio, 7756-7703 Floyd Curl Drive San Antonio, TX 78229, USA
}

Compelling evidence shows that intracellular free magnesium $\left[\mathrm{Mg}^{2+}\right]_{\mathrm{i}}$ may be a critical regulator of cell activity in eukaryotes. However, membrane transport mechanisms mediating $\mathrm{Mg}^{2+}$ influx in mammalian cells are poorly understood. Here, we show that mechanosensitive (MS) cationic channels activated by stretch are permeable for $\mathrm{Mg}^{2+}$ ions at different extracellular concentrations including physiological ones. Single-channel currents were recorded from cell-attached and inside-out patches on $\mathrm{K} 562$ leukaemia cells at various concentrations of $\mathrm{MgCl}_{2}$ when $\mathrm{Mg}^{2+}$ was the only available carrier of inward currents. At $2 \mathrm{mM} \mathrm{Mg}^{2+}$, inward mechanogated currents representing $\mathrm{Mg}^{2+}$ influx through MS channels corresponded to the unitary conductance of about $5 \mathrm{pS}$. At higher $\mathrm{Mg}^{2+}$ levels, only slight increase of single-channel currents and conductance occurred, implying that $\mathrm{Mg}^{2+}$ permeation through MS channels is characterized by strong saturation. At 20 and $90 \mathrm{mM} \mathrm{Mg}^{2+}$, mean conductance values for inward currents carried by $\mathrm{Mg}^{2+}$ were rather similar, being equal to $6.8 \pm 0.5$ and $6.4 \pm 0.5 \mathrm{pS}$, respectively. The estimation of the channel-selective permeability according to constant field equation is obviously limited due to saturation effects. We conclude that the detection of single currents is the main evidence for $\mathrm{Mg}^{2+}$ permeation through membrane channels activated by stretch. Our single-current measurements document $\mathrm{Mg}^{2+}$ influx through MS channels in the plasma membrane of leukaemia cells.

Cell Research (2006) 16:723-730. doi:10.1038/sj.cr.7310084; published online 25 July 2006

Keywords: magnesium, single currents, mechanosensitive channel, human leukaemia cell

\section{Introduction}

Magnesium plays an important role in a large number of cellular processes acting as a cofactor in enzymatic reactions and transmembrane ion movements. With improved methods for measuring intracellular ionized $\mathrm{Mg}^{2+}$ concentration $\left(\left[\mathrm{Mg}^{2+}\right]_{\mathrm{i}}\right)$, it has been established that $\left[\mathrm{Mg}^{2+}\right]_{\mathrm{i}}$ is maintained below electrochemical equilibrium in all cells investigated to date. Most eukaryotic cells appear to contain a Na $/ \mathrm{Mg}^{2+}$ exchanger that use the transmembrane Na gradient to expel $\mathrm{Mg}^{2+}$. There is also evidence for $\mathrm{Mg}^{2+}$ : $\mathrm{Cl}^{-}$and $\mathrm{Mg}^{2+}: \mathrm{H}^{+}$transporters $[1,2]$. It has been accepted

\footnotetext{
"These two authors contributed equally to this paper. Correspondence: Yuri A Negulyaev

Tel: +812+2971497;

E-mail: yurineg@mail.cytspb.rssi.ru

Received, 15 Jun 2005; revised, 6 May 2006; accepted, 5 Jun 2006; published online 25 Jul 2006
}

that $\mathrm{Mg}^{2+}$ content is kept constant at the level necessary for enzyme and channel function. Even small changes in internal levels of $\mathrm{Mg}^{2+}$ could have dramatic effects on cell activity. However, in the last decade, a number of new experimental observations have revealed that large fluxes of $\mathrm{Mg}^{2+}$ can cross the cell membrane in either direction following a variety of hormonal or non-hormonal stimuli [3]. Insulin, vasopressin, angiotensin and some other agonists induce cellular $\mathrm{Mg}^{2+}$ accumulation, at least partially, by stimulating $\mathrm{Mg}^{2+}$ entry from the extracellular fluid, while adrenergic agonists stimulate cellular $\mathrm{Mg}^{2+}$ release. It is unknown whether $\mathrm{Mg}^{2+}$ release and accumulation are accomplished by the same transporters operating in either direction or by distinct transport mechanisms in the plasma membrane. Little is known about membrane pathways mediating $\mathrm{Mg}^{2+}$ influx in eukaryotes. Voltageclamp studies have provided evidence for the operation of a $\mathrm{Mg}^{2+}$-specific current in Paramecium $[4,5]$. Using single-current recording, a $\mathrm{Mg}^{2+}$-permeable cation chan- 
nel in spinach thylakoid membranes has been described [6]. For mammalian cells, the data are scarce, especially on the single-channel level. The possibility that $\mathrm{Mg}^{2+}$ may cross the plasma membrane via a channel is appealing and indirectly supported by inhibitory effects of channel blockers on $\mathrm{Mg}^{2+}$ accumulation [3]. The examination of renal $\mathrm{Mg}^{2+}$ handling at the tubular and cellular levels is also consistent with the assumption that the $\mathrm{Mg}^{2+}$-permeable channel functions in apical membranes [7]. Moreover, evidence has accumulated to suggest that extracellular $\mathrm{Mg}^{2+}$ concentration can rapidly regulate intracellular $\mathrm{Mg}^{2+}$ and has functional effects in a variety of tissues under physiological conditions and in pathophysiology. Specifically, dynamic changes in free $\mathrm{Mg}^{2+}$ have been shown to play a pivotal role in endothelial cell functions $[8,9]$ and in the brain following neurotrauma [10]. Now $\mathrm{Mg}^{2+}$ is considered a promising neuroprotective agent in the therapy of acute ischaemic stroke and vascular damages. A question arises whether cation-selective channels could be involved in the $\mathrm{Mg}^{2+}$-transporting system in plasma membrane of mammalian cells. In recent years, data have appeared suggesting that TRP membrane proteins, specifically some members of TRPM subfamily, may function as $\mathrm{Ca}^{2+}$ - and $\mathrm{Mg}^{2+}$-permeable cation channels [11-14]. It has been assumed that they are involved in cellular magnesium homeostasis. The aim of the present study is to directly estimate magnesium permeation through mechanosensitive (MS) channels that are considered to be ubiquitously present in various cell types. In our previous paper, gadolinium-blockable MS cationic channels have been identified and characterized in human leukaemia K562 cells [15]. Here, special attention has been paid to the detection of mechanogated singlechannel currents carried by $\mathrm{Mg}^{2+}$ ions.

\section{Materials and Methods}

\section{Cells}

Human myeloid leukaemia K562 cells were obtained from Cell Culture Collection (Institute of Cytology, St Petersburg, Russia) and were maintained in glass flasks in RPMI-1640 containing $10 \%$ fetal bovine serum and antibiotics $(100 \mathrm{mg} / \mathrm{ml}$ streptomycin and 100 units $/ \mathrm{ml}$ penicillin or $80 \mathrm{mg} / \mathrm{ml}$ gentamycin) at $37{ }^{\circ} \mathrm{C}$. Cells were plated on coverslips $(0.4 \times 0.4 \mathrm{~cm}) 1-3$ days before experiment.

\section{Electrophysiology}

Single-channel currents were recorded using standard cell-attached mode of the patch-clamp technique [16]. Pipettes were pulled from soft glass capillaries to a resistance of 7 15 $\mathrm{M} \Omega$ when filled with solution. Membrane currents were measured essentially as described earlier $[15,17]$. Membrane voltage was the potential of the intracellular membrane side minus the potential of the extracellular one. Unless otherwise stated, data were filtered at 200 $\mathrm{Hz}$ and sampled at a rate of $1 \mathrm{kHz}$ by 12-bit ADC for analysis and display. The recordings were performed at room temperature (22 23 ${ }^{\circ} \mathrm{C}$ ) on the stage of an inverted microscope with Nomarsky optics (magnification of $256 \times$ ). We used well-known method of mechanical stimulation of applying pressure to a patch pipette. A "gentle" seal was essential for the formation of the patch as well as for the application of stimulus to activate the channels. The pipette interior was connected to a manometer with a valve to allow either application of negative (positive) pressure or equilibration to atmospheric pressure. Mechanically gated ion channels were activated in response to the negative pressure application (suction). Pressure range was $1.333-2.666 \mathrm{kPa}(10-20 \mathrm{mmHg})$.

\section{Data analysis}

Channel open probability $\left(P_{\mathrm{o}}\right)$ was determined using the following equation:

$$
\text { (1) } P_{\mathrm{o}}=\frac{I}{i N},
$$

where $I$ is the mean current determined from the amplitude histograms, $i$ is the unitary current amplitude and $N$ is the number of functional channels.

Single-channel conductance values were determined by the slope of the current-voltage $(I-V)$ curve, where the $I-V$ data could be well fitted to a straight line. The relative permeability ratios of the channel $\left(P_{\mathrm{Mg}} / P_{\mathrm{K}}\right)$ were defined as

(2) $\frac{P_{\mathrm{Mg}}}{P_{\mathrm{K}}}=\frac{[\mathrm{K}]_{\mathrm{i}}}{4[\mathrm{Mg}]_{\mathrm{o}}} \exp \left(E_{\mathrm{rev}} F / R T\right)\left\{\exp \left(E_{\mathrm{rev}} F / R T\right)+1\right\}$,

where the reversal potential $E_{\text {rev }}$ was obtained by fitting the $I-V$ curve. Subscripts i and o represent inside and outside of the membrane, and other parameters have their usual meanings. When free intracellular $\mathrm{Mg}^{2+}$ was also taken into account, we used modified Goldman-Hodgkin-Katz current equation [18]. The effect of the ionic strength of the solution on the activity of each ion is considered. Activity coefficients were calculated according to the extended Debye-Hückel equation:

$$
-\log (\gamma)=\frac{A z^{2} \sqrt{\mu}}{1+B a \sqrt{\mu}}
$$

where $\gamma$ is the activity coefficient, $z$ is the charge of the ion, $\mu$ is the ionic strength of the aqueous solution, $A$ and $B$ are constants and $\alpha$ is an effective diameter of the hydrated ion. Averaged data are given as the mean \pm s.e.m. (number of experiments).

\section{Solutions}

The bath solution for cell-attached measurements contained (in $\mathrm{mM}$ ): $145 \mathrm{KCl}, 2 \mathrm{CaCl}_{2}, 1 \mathrm{MgCl}_{2}$ and $10 \mathrm{HEPES} / \mathrm{KOH}$. In control experiments, pipettes were filled with normal external solution (in $\mathrm{mM}$ ): $145 \mathrm{NaCl}, 2 \mathrm{CaCl}_{2}, 1 \mathrm{MgCl}_{2}$ and $10 \mathrm{HEPES} /$ Tris-OH. To measure $\mathrm{Mg}^{2+}$ currents, we used pipette solutions with different concentrations of $\mathrm{Mg}^{2+}$ supplemented with NMDG to maintain the tonicity and ionic strength. Solution of high $\mathrm{Mg}^{2+}$ contained (in $\mathrm{mM}$ ): $90 \mathrm{MgCl}_{2}$ and $10 \mathrm{HEPES} / \mathrm{Tris}-\mathrm{OH}$. Solutions of lower $\mathrm{Mg}^{2+}$ concentrations contained (in $\mathrm{mM}$ ): $20 \mathrm{MgCl}_{2}+110 \mathrm{NMDGCl}, 2 \mathrm{MgCl}_{2}+$ $137 \mathrm{NMDGCl}$ and $1 \mathrm{MgCl}_{2}+138 \mathrm{NMDGCl}$. In some experiments, 0.1-0.2 mM EGTA/Tris-OH was added to the magnesium pipette solutions to exclude any impurities by divalent or trivalent cations. Bath cytosol-like solution for inside-out measurements contained (in mM): $145 \mathrm{KAsp}$ or $\mathrm{KCl}, 1 \mathrm{MgCl}_{2}, 20 \mathrm{HEPES} / \mathrm{KOH}, 2$ EGTA and 
an appropriate quantity of $\mathrm{CaCl}_{2}(0.175)$ to establish the final free ionized calcium concentration at the desired level of $0.01 \mathrm{mkM} . \mathrm{pH}$ of all solutions buffered with $10 \mathrm{HEPES} /$ Tris-OH was set at 7.3. All chemicals were purchased from Sigma.

\section{Results}

Gadolinium-blockable MS channels in the plasma membrane of K562 leukaemia cells have been previously shown to be cation-selective and fully impermeable to large organic cations, such as $\mathrm{NMDG}^{+}$and $\mathrm{Tris}^{+}[15]$. To search for the magnesium permeability of MS channels, cell-attached measurements in the presence of 90, 20, 2 and $1 \mathrm{mM} \mathrm{MgCl}{ }_{2}$ in the pipette solution were performed. $\mathrm{Mg}^{2+}$ was the only available carrier for inward current; other cations in the pipette were impermeable $\mathrm{NMDG}^{+}$and Tris $^{+}$. It was specifically evaluated that there was no inward current through MS channels when the pipette contained only $\mathrm{NMDG}^{+}$and $\mathrm{Tris}^{+}$cations, in full agreement with the previous results [15]. MS channel activity was initiated by negative pressure application (suction, see also Materials and Methods). Representative recordings shown in
Figure 1 demonstrate an activation of inward currents in response to suction in control experiment $\left(\mathrm{Na}^{+}\right.$-containing

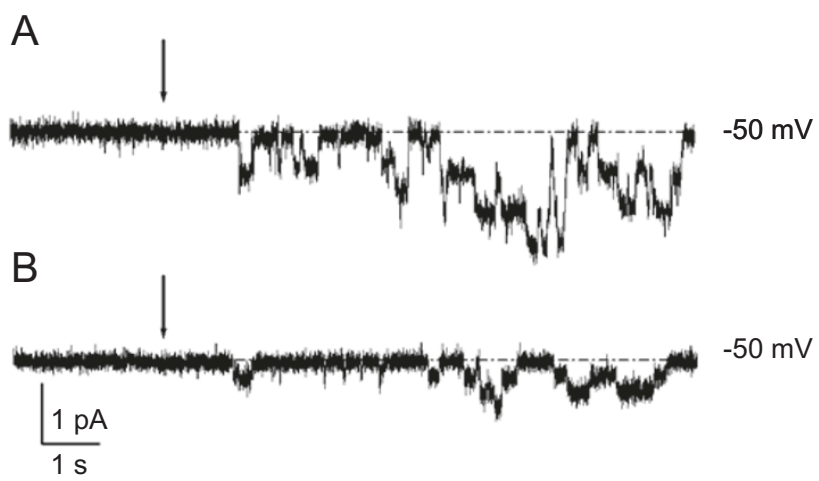

Figure 1 Mechanogated currents recorded from representative cell-attached patches on K562 cells: (A) in control experiment with $\mathrm{Na}^{+}$-containing solution in the pipette and (B) in the presence of $\mathrm{Mg}^{2+}(20 \mathrm{mM})$ as the only permeant cation in the pipette solution. The application of suction is indicated by the arrows.

A
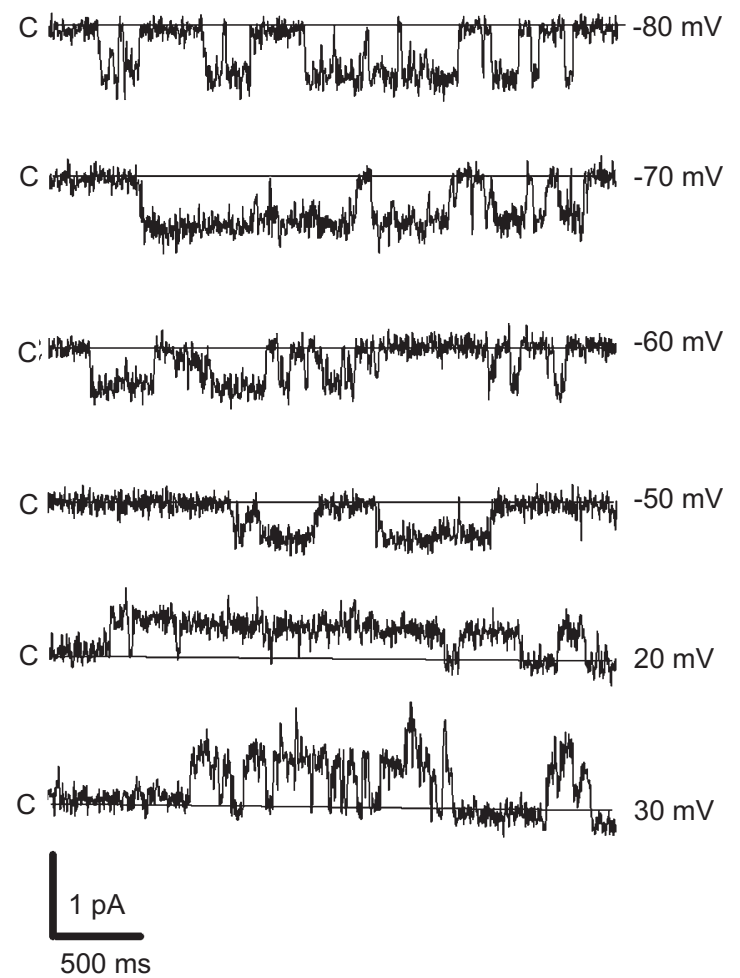

B
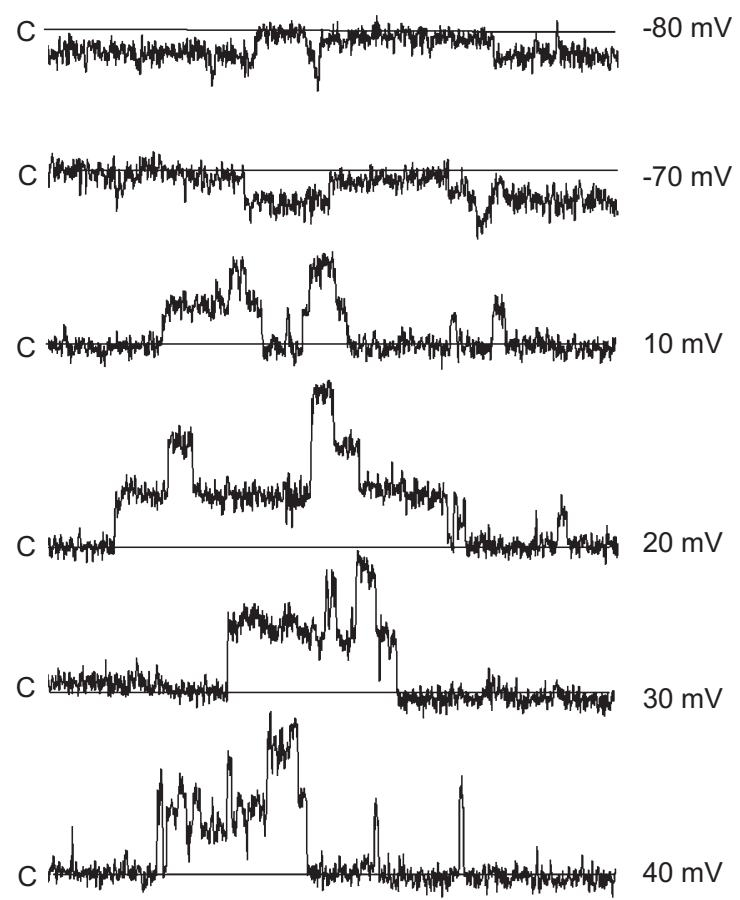

Figure 2 MS channel activity recorded from cell-attached patches at applied negative pressure when $\mathrm{Mg}^{2+}$ was the only available carrier of the inward current. Pipette solution contained: $90 \mathrm{mM} \mathrm{MgCl}_{2}, 10 \mathrm{mM} \mathrm{HEPES} /$ Tris (A) or $2 \mathrm{mM} \mathrm{MgCl} 2,137 \mathrm{mM} \mathrm{NMDGCl}$, $10 \mathrm{mM}$ HEPES/Tris (B). Holding membrane potentials are indicated near traces; $\mathrm{c}$ - closed states. 

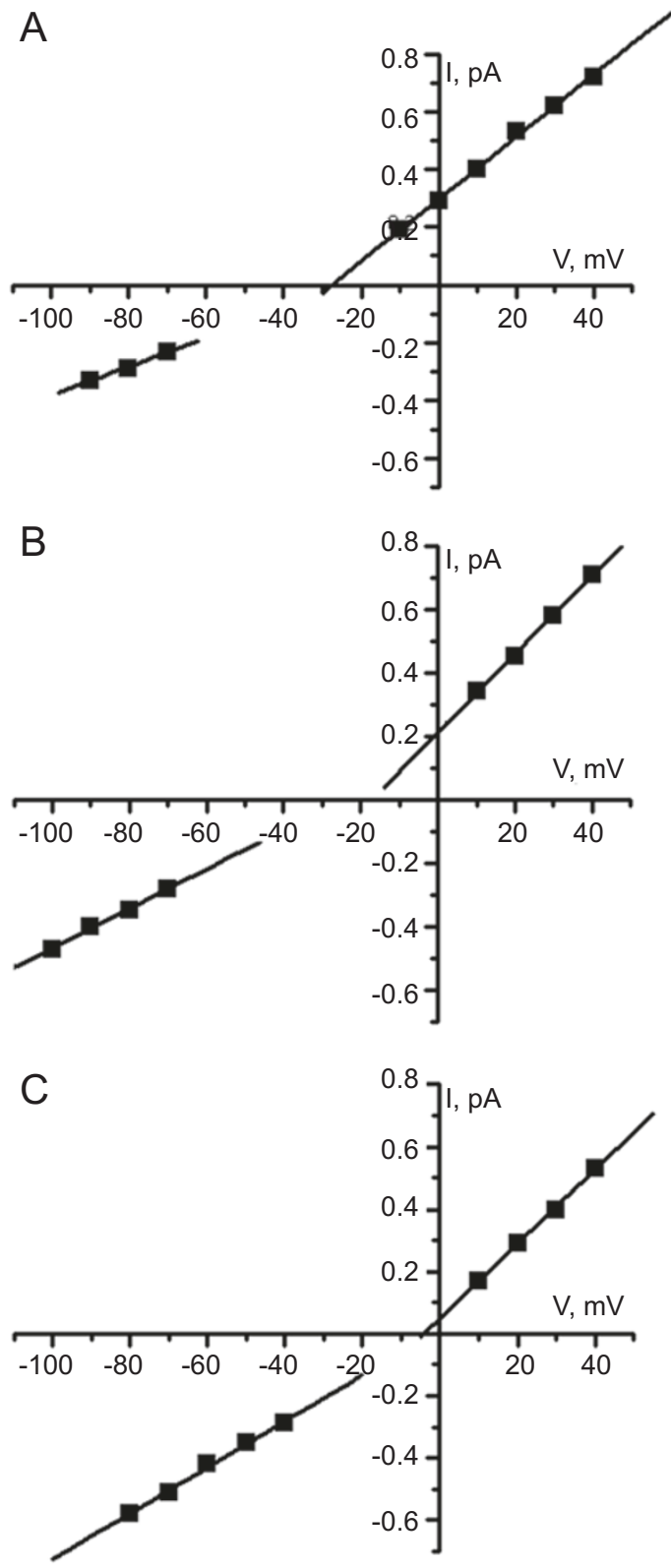

Figure 3 Permeation of MS channels for magnesium ions. Currentvoltage relationships measured in cell-attached experiments with various $\mathrm{Mg}^{2+}$ concentrations in the pipette solution: (A) $2 \mathrm{mM} \mathrm{MgCl}_{2}$, (B) $20 \mathrm{mM} \mathrm{MgCl}_{2}$ and (C) $90 \mathrm{mM} \mathrm{MgCl}$. $\mathrm{NMDG}^{+}$was used for cationic substitution. Inward currents represent magnesium influx through MS channels.

solution in the pipette) and in the presence of $20 \mathrm{mM} \mathrm{Mg}^{2+}$ supplemented with $\mathrm{NMDG}^{+}$in the pipette. In the control experiments, MS channels were found in $55 \%(n=479)$ of cell-attached patches. Mechanogated currents were also observed in 53\% $(n=173)$ of stable cell-attached patches in the presence of $\mathrm{Mg}^{2+}$ as the only permeable cation in the pipette solution. At all applied concentrations of $\mathrm{MgCl}_{2}$, single openings representing MS channel activity were observed over a wide range of membrane potentials (Figures 1 and 2). Outward or inward unitary currents activated by negative pressure application could be measured (Figure 2). Importantly, inward single-channel currents carried by $\mathrm{Mg}^{2+}$ cations were detected. These data show that MS channels are permeable to $\mathrm{Mg}^{2+}$ at physiological concentration range $(1 \sim 2 \mathrm{mM})$ as well as at higher level of $\mathrm{Mg}^{2+}(20$ and $90 \mathrm{mM}$ ) in the extracellular (pipette) solution (Figures 1-3). When 0.1-0.2 mM EGTA/Tris-OH was added to the pipette solution to avoid potential impurities, very similar currents and conductance were measured.

Mechanogated currents of outward direction appeared to represent intracellular monovalent (presumably, potassium) ion efflux (cell-attached recordings, Figure 2). Corresponding single-channel conductance measured at positive potentials $(12.1 \pm 0.6 \mathrm{pS}, n=22)$ did not change when varying the $\mathrm{Mg}^{2+}$ concentration in the extracellular solution. Inward currents carried by $\mathrm{Mg}^{2+}$ corresponded to the lower values of unitary conductance; current-voltage relationships displayed slight outward rectification (Figure 3 ). In the presence of $2 \mathrm{mM} \mathrm{Mg}^{2+}$ in the pipette, the currentvoltage relationship, measured for MS channel activity of inward direction, showed a unitary conductance value of 5 $\mathrm{pS}$. In the presence of 20 and $90 \mathrm{mM} \mathrm{MgCl}{ }_{2}$ in the pipette, mean conductance values for inward currents carried by $\mathrm{Mg}^{2+}$ were similar, being equal to $6.8 \pm 0.5(n=13)$ and 6.4 $\pm 0.5(n=8) \mathrm{pS}$, respectively. Thus, single-channel currents and conductance values show that $\mathrm{Mg}^{2+}$ permeation through MS channels is characterized by strong saturation effect.

The reversal potential values could be obtained from current-voltage relationships by extrapolation of linear sections at positive and at negative membrane voltage (Figure 3). Mean values were equal to $-27.4 \pm 2.7(n=5)$, $-16.0 \pm 1.9(n=5)$ and $-5.2 \pm 1.1(n=9) \mathrm{mV}$ at 2,20 and $90 \mathrm{mM} \mathrm{MgCl} 2$ in the pipette, respectively. Increasing of $\mathrm{Mg}^{2+}$ from 1 to $90 \mathrm{mM}$ resulted in a shift of the reversal potential value to the positive direction providing additional evidence that inward currents objectively represented $\mathrm{Mg}^{2+}$ influx through MS channels. The relative permeability of the channel was estimated from reversal potential data according to modified Goldman-Hodgkin-Katz equation [18]. Intracellular $\mathrm{K}^{+}$concentration was assumed to be equal to $140 \mathrm{mM}$. Intracellular $\mathrm{Mg}^{2+}$ was assumed to be 0 or $0.5 \mathrm{mM}$ and similar values of permeability ratio have been obtained in both cases. The activity coefficients for cations were calculated according to the extended Debye-Hückel equation: $\mathrm{g}_{\mathrm{K}}=0.73$ and $\mathrm{g}_{\mathrm{Mg}}=0.35$. Taking into account the activity coefficients, the relative permeability value $\left(P_{\mathrm{Mg}} / P_{\mathrm{K}}\right)$ estimated from reversal potential value of $-27 \mathrm{mV}$ (at $2 \mathrm{mM}$ extracellular $\mathrm{Mg}^{2+}$ ) was equal to 18 . This 


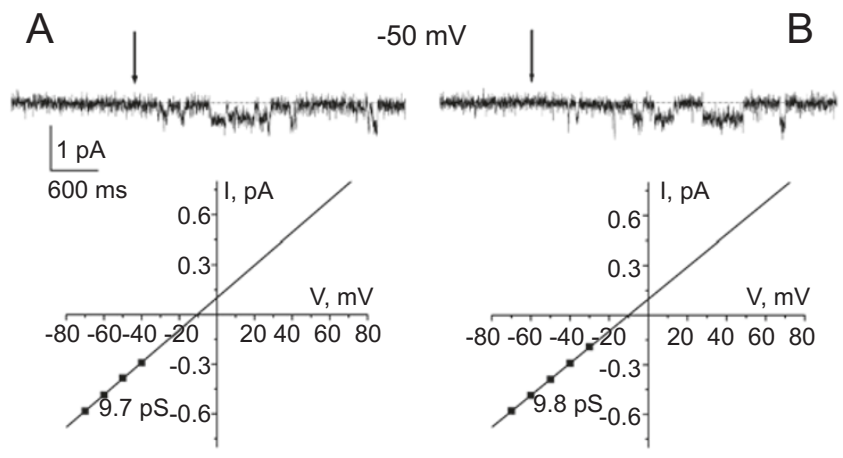

Figure 4 Inside-out recordings of MS channel activity and corresponding current-voltage relationships obtained with anion replacement in the cytosol-like solution: $140 \mathrm{mM} \mathrm{KAsp} \mathrm{(A)} \mathrm{or} \mathrm{KCl}$ (B). Pipette solution contained $20 \mathrm{mM} \mathrm{MgCl}_{2}, 110 \mathrm{mM} \mathrm{NMDGCl}$ and $10 \mathrm{mM}$ HEPES/Tris. The application of suction is indicated by the arrows.

implies $\mathrm{Mg}^{2+}$ selectivity of the MS channel. However, this estimation should be considered as rough approximation since unitary currents and conductance displayed saturating $\mathrm{Mg}^{2+}$ influx when $\mathrm{Mg}^{2+}$ concentration was raised above physiological level. Therefore, it would be quite incorrect to estimate channel selectivity from reversal potential measurements at higher $\mathrm{Mg}^{2+}$ concentrations in the pipette solution. Moreover, it is reasonable to conceive that deviations from independence for $\mathrm{Mg}^{2+}$ fluxes may occur even at low concentrations. Calculations according constant field equation for 20 and $90 \mathrm{mM} \mathrm{Mg}^{2+}$ give $P_{\mathrm{Mg}} / P_{\mathrm{K}}$ values of about 3 and 1, respectively. There are very inconsistent values that have been calculated from reversal potential data at various bivalent concentrations. Thus, the detection of single currents carried by $\mathrm{Mg}^{2+}$ is the primary source to characterize permeation properties of the channels.

In our previous studies, high cation/anion selectivity of MS channels in leukaemia cells has been indicated using several series of ion-substitution experiments [15]. Nevertheless, to address the possibility that $\mathrm{Cl}$ - flux might be involved in the inward currents recorded from cell-attached patches, additional experiments on excised fragments were performed. MS channel activity was recorded from insideout patches on K562 cells in the presence of aspartate as a main anion in the bath of cytosol-like solution (Figure 4A); $\mathrm{Mg}^{2+}(20 \mathrm{mM})$ was the only available carrier for inward currents in the pipette solution. Single-channel conductance for inward currents activated by suction was equal to $8.5 \pm$ $0.6 \mathrm{pS}$. Additional evidence to identify the inward currents as $\mathrm{Mg}^{2+}$ influx has been obtained in inside-out experiments with anionic substitution. Figure 4 shows mechanogated currents recorded from inside-out patch in the presence of aspartate or chloride in the bath solution and $\mathrm{Mg}^{2+}$ as the

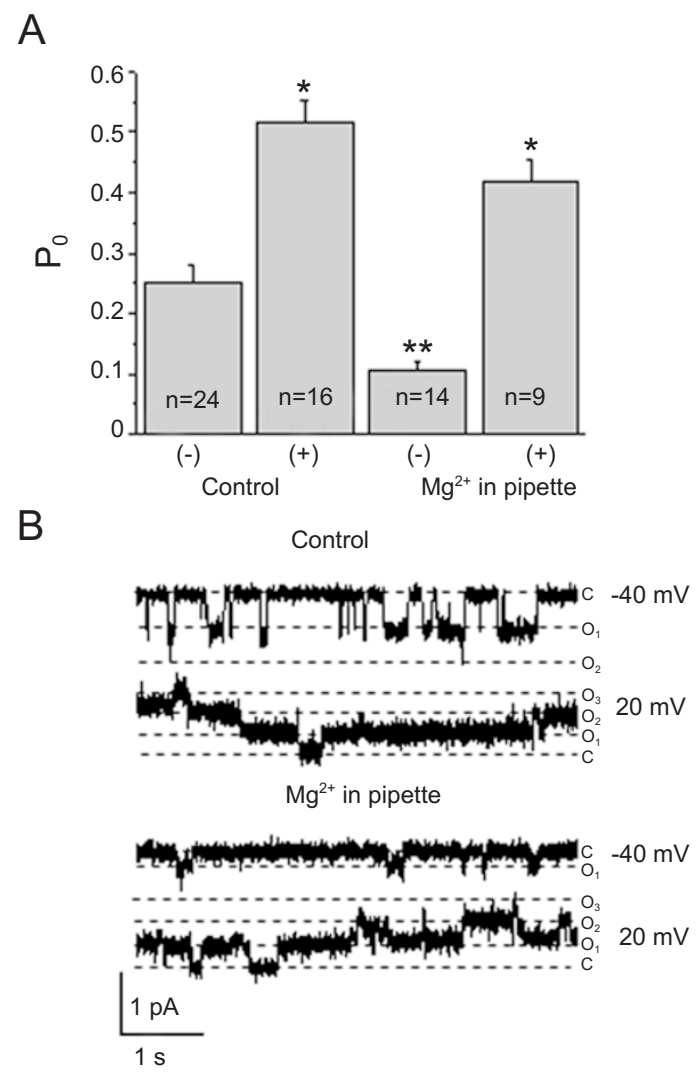

Figure 5 Effect of membrane voltage on channel activity in cell-attached patches in presence of $\mathrm{Na}^{+}$(145 mM, control) or $\mathrm{Mg}^{2+}(90$ $\mathrm{mM})$ as a main cation in the pipette solution. (A) Mean open probability $\left(P_{\mathrm{o}}\right)$ values represent different levels of MS channel activity for inward (-) and outward (+) currents. (B) Typical current records obtained at the membrane potential $-40 \mathrm{mV}$ (inward currents) and $+20 \mathrm{mV}$ (outward currents) in control or at high concentration of $\mathrm{Mg}^{2+}$ in the pipette.

only permeant cation in the pipette. Inside-out recordings demonstrate that substitution of anions in the cytosol-like solution caused no changes in the amplitude of singlechannel openings.

It is known that macroscopic ionic currents underlying membrane transport considerably depend on kinetic properties of single channels and on the level of channel activity. MS channels in K562 cells were shown to be active throughout the range of holding membrane potentials $[15,19]$. Figure 5 shows the effect of membrane voltage on channel activity in cell-attached patches in the presence of $\mathrm{Na}^{+}\left(145 \mathrm{mM}\right.$, control) or $\mathrm{Mg}^{2+}(90 \mathrm{mM})$ as a main cation in the pipette solution. In the presence of $\mathrm{Na}^{+}$, MS channel activity estimated as open probability $\left(P_{\mathrm{o}}\right)$ displayed obvious voltage sensitivity (Figure $5 \mathrm{~A}$, on the left): $P_{\mathrm{o}}$ at positive voltages was higher than that at negative voltages, in agreement with our previous data for control patches on 


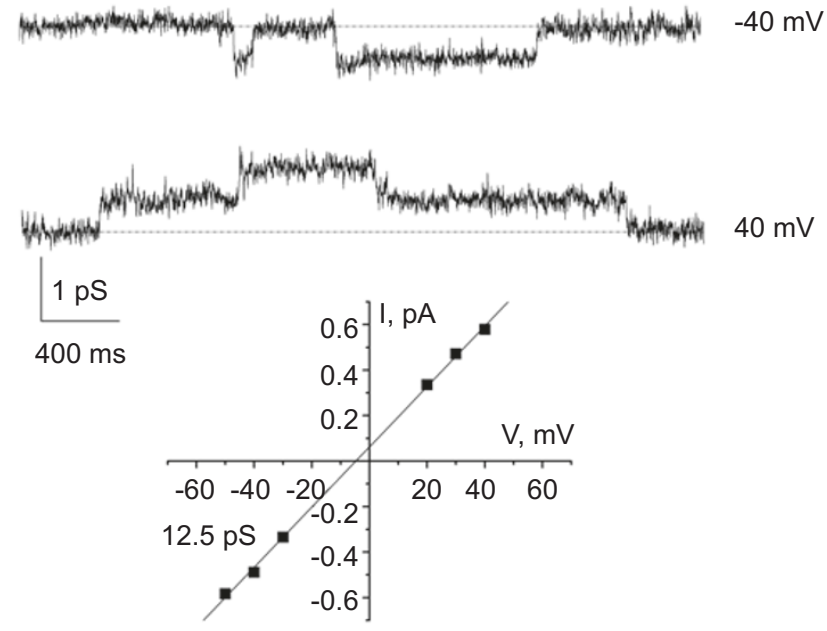

Figure 6 Mechanogated currents and corresponding current-voltage relationship obtained on an inside-out patch when $\mathrm{Mg}^{2+}(20 \mathrm{mM}$ $\left.\mathrm{MgCl}_{2}\right)$ was added to $\mathrm{Na}$-containing $(115 \mathrm{mM} \mathrm{NaCl})$ pipette solution. Bath solution contained $115 \mathrm{mM} \mathrm{NaCl}$ and $30 \mathrm{mM}$ NMDGCl.

K562 cells [19]. Figure 5A also shows evident differences of open probability values for inward and outward currents in the presence of $90 \mathrm{mM} \mathrm{MgCl}{ }_{2}$ in pipette solution: mean $P_{\mathrm{o}}$ at negative potentials (inward currents carried by $\mathrm{Mg}^{2+}$ ) was considerably lower than at positive potentials (outward currents). Representative current records (Figure 5B) additionally demonstrated that at high external $\mathrm{Mg}^{2+}$ concentrations, channel activity strongly depended on membrane voltage or on current direction. A comparison of mean open probabilities obtained for negative voltage ranges revealed that $P_{\mathrm{o}}$ value is lower for $\mathrm{Mg}^{2+}$-transported currents than correspondent $P_{\mathrm{o}}$ for monovalent currents through MS channels (Figure 5A). It is reasonable to suggest that on an integral current level, this effect may also contribute to the saturation or even inhibition of $\mathrm{Mg}^{2+}$ influx.

Single-current records clearly demonstrate permeation of magnesium when the divalent is the only charge carrier. Direct measurements of unitary currents carried by $\mathrm{Mg}^{2+}$ ions together with the estimation of permeability ratio allow one to assume that the channel activity may contribute to $\mathrm{Mg}^{2+}$ entry at physiological levels of extracellular $\mathrm{Mg}^{2+}$. However, it remains unclear whether the possible contribution of MS channels in $\mathrm{Mg}^{2+}$ transport really occurs under physiological ionic conditions in the presence of competition between extracellular $\mathrm{Mg}^{2+}$ and $\mathrm{Na}^{+}$. We tried to test this possibility using current recording from inside-out patches bathed in Na-containing solutions when $\mathrm{Mg}^{2+}$ ions were added only from the extracellular membrane side. It should be noted that MS channel activity in inside-out patches was characterized by less stability as compared to cell-attached patches. Figure 6 shows the results of the experiment in which outward and inward currents recorded from the same inside-out patch could be compared. Inward and outward currents corresponded to very similar conductance values (12.5 pS), thus providing no evidence that the channel carries $\mathrm{Mg}^{2+}$ in the presence of sodium.

\section{Discussion}

Our data document $\mathrm{Mg}^{2+}$ permeation through MS channels in the plasma membrane of K562 leukaemia cells. The estimation of selectivity in terms of permeability ratios using the constant field equation gave rather high values of $P_{\mathrm{Mg}} / P_{\mathrm{K}}$, implying the channel is $\mathrm{Mg}^{2+}$-selective. However, it is reasonable to consider that the application of constant field equation is very limited because of strong saturation of single-channel $\mathrm{Mg}^{2+}$ currents and conductance. Therefore, the detection of inward single currents at various $\mathrm{Mg}^{2+}$ concentrations is stronger evidence for $\mathrm{Mg}^{2+}$ permeation via MS channels when magnesium is the only charge carrier.

Numerous works described inhibitory or modulatory effects of extracellular and intracellular $\mathrm{Mg}^{2+}$ on various MS cationic channels, whereas their permeability for $\mathrm{Mg}^{2+}$ remained largely unknown. Particularly, stretch-activated $\mathrm{K}^{+}$channels in Lymnaea stagnalis and TREK-1, an MS K channel, have been found to be blocked by external $\mathrm{Mg}^{2+}$ $[20,21]$. Wu et al. [22] suggested that $\mathrm{Mg}^{2+}$ permeated and blocked MS channels and this effect partly contributed to the inward rectification. To address $\mathrm{Ca}^{2+}$ or $\mathrm{Mg}^{2+}$ permeation, single currents were recorded routinely at extremely high concentrations of bivalent cations in the extracellular solutions (pipette solution in the case of cell-attached). However, it was shown that channel properties strongly depended on the permeant ion concentration [23]. Recently, we have also demonstrated that permeation and blocking effects of $\mathrm{Ca}^{2+}$ on MS channels were critically dependent on the external $\mathrm{Ca}^{2+}$ level [15]. These data emphasize that concentration range is of primary importance for the correct estimation of channel permeability properties. Notably, in the present work, we managed to record inward single-channel currents carried by $\mathrm{Mg}^{2+}$ in the wide range of external concentration including rather low level (1-2 $\mathrm{mM}$ ) that is similar to physiological values.

A number of observations indicate electrodiffusive transfer of $\mathrm{Mg}^{2+}$ consistent with transport through a channel in specialized renal epithelia [7]. In a variety of cells of different specialization, $\mathrm{Mg}^{2+}$ entry via non-specific cation channels has been suggested. $\mathrm{Mg}^{2+}$ influx through $\mathrm{Ca}^{2+}$ channels was observed in frog motor nerve terminals [24]. ADP-induced integral currents carried by different cations, including $\mathrm{Ca}^{2+}, \mathrm{Ba}^{2+}$ and $\mathrm{Mg}^{2+}$ (at $110 \mathrm{mM}$ ), have been found in megakaryocytes [25]. The ability of $\mathrm{Mg}^{2+}$ 
to pass through and to carry substantial currents has been shown for the RyR channel [26] and for the $\mathrm{IP}_{3}$-gated channel from the cerebellum [27]. The authors suggest that $\mathrm{Mg}^{2+}$ ions are able to keep their inner shell of water molecules when they pass through the selectivity filters of both intracellular $\mathrm{Ca}^{2+}$ channels. The non-selective voltage-activated cation channel in human red blood cells was reported to be permeable for $\mathrm{Ca}^{2+}$ and $\mathrm{Ba}^{2+}$, and even $\mathrm{Mg}^{2+}$; currents were also recorded at extremely high extracellular divalent concentrations [28]. Measurements of macroscopic $\mathrm{Mg}^{2+}$ currents in Paramecium gave a rare example of a membrane conductance that was strongly $\mathrm{Mg}^{2+}$-specific [5]. The physiological contribution of $\mathrm{Mg}^{2+}$ current to normal membrane excitability and behaviour in this ciliate has been proposed.

Although data suggesting the existence of $\mathrm{Mg}^{2+}$ channels have been observed in Paramecium, functional identification of membrane transport mechanisms for $\mathrm{Mg}^{2+}$ entry in other eukaryotic cells was considered to be an unsolved question. Recently, the members of TRP family, namely TRPM subfamily, have been described as $\mathrm{Ca}^{2+}$ - and $\mathrm{Mg}^{2+}$-permeable channels and their implication in cellular magnesium homeostasis has been assumed $[12,13]$. Specifically, electrophysiological analysis of HEK-293 cells overexpressing recombinant LTRPC7 (TRPM7) showed large currents regulated by millimolar levels of Mg-ATP and Mg-GTP, with the permeation properties of a voltage-independent divalent cation pathway $[11,29] . \mathrm{Mg}^{2+}$ permeation and block of the TRPM6-induced channels were characterized using different approaches, particularly significant inward whole-cell currents were measured in the presence of $20 \mathrm{Mg}^{2+}$ and $120 \mathrm{NMDG}^{+}$in the external solution [14]. The genetic analysis together with the expression studies and functional channel characteristics highlight a crucial role of TRPM6 for epithelial $\mathrm{Mg}^{2+}$ transport [13]. Alternatively, a participation of different members of the TRP family in the formation of physiologically active $\mathrm{Mg}^{2+}$ channel is hypothesized. Various functions of TRP channels have been proposed that are correlated with their diverse activation properties [30]. It is of interest that the activation mechanism of TRPV4 channel is linked to hypotonic cell swelling and its expression pattern is assumed to be in agreement with a possible role as an osmo- or volume sensor [30, 31]. Our single-current data allow us to speculate that MS stretch-activated channels could participate in passive cation transport and $\mathrm{Mg}^{2+}$ regulation in mammalian cells. Convincing evidence has shown that MS channels are ubiquitously present in various cell types [32, 33]. Stretch-activated channels described in specialized mammalian cells are thought to be involved in mechanical signal transduction. However, in a large number of non-specialized cells, the functional significance as well as molecular identification of cation-permeable MS channels is poorly understood. Two roles are usually proposed: to pass cations (mainly $\mathrm{Na}^{+}$) leading to membrane depolarization, and to pass $\mathrm{Ca}^{2+}$ to increase the free cytosolic $\mathrm{Ca}^{2+}$ concentration either directly or indirectly (by triggering $\mathrm{Ca}^{2+}$ release from stores in muscle cells). Evidence for $\mathrm{Ca}^{2+}$ permeability has been obtained using fluorescence measurements and single-current recordings at physiological $\mathrm{Ca}^{2+}$ levels $[15$, 34]. Measurements of $\mathrm{Mg}^{2+}$ currents and permeability for MS channels imply that additional functional roles could be considered, particularly in cells of blood origin. An essential point that needs to be addressed is to obtain direct evidence for $\mathrm{Mg}^{2+}$ influx under physiological conditions. To demonstrate $\mathrm{Mg}^{2+}$ entry into the cytosol via the channels, other approaches would be required in addition to singlecurrent identification.

Our patch-clamp recordings show strong saturation effect of inward currents carried by $\mathrm{Mg}^{2+}$ : the amplitude of single-channel currents did not significantly increase with the rise of the $\mathrm{Mg}^{2+}$ concentration in the solution from the extracellular membrane side. These data correlate with the recent observations, indicating that large variations in magnesemia (an elevation of circulating $\mathrm{Mg}^{2+}$ level) are well tolerated in vivo [3]. It is worth noting that the absence of apparent physiological effects despite the magnitude of the increase in serum $\mathrm{Mg}^{2+}$ level is a striking difference with a comparable increase in serum $\mathrm{Ca}^{2+}$, which induces muscle weakness and arrhythmia.

The saturation of currents and conductance may be due to characteristics of hydratation-dehydratation reactions of the $\mathrm{Mg}^{2+}$ ion. In terms of barrier models, the ion-transporting pore appears to include highly saturable binding site for $\mathrm{Mg}^{2+}$ that is consistent with known slow dehydratation for this cation. $\mathrm{Mg}^{2+}$ currents corresponded to the lower unitary conductance compared to $\mathrm{K}^{+}$or $\mathrm{Na}^{+}$ currents (Figure 2). Accordingly, there is evident difference in the description of channel selectivity in terms of conductance ratios or permeability ratios calculated from reversal potentials. This observation somewhat resembles a dramatic deviation from independence described earlier in classical studies on proton permeability of sodium channels $[35,18]$. In conclusion, our single-current measurements provide evidence for $\mathrm{Mg}^{2+}$ permeation through MS cation channels and allow one to assume their possible involvement in membrane transport mechanisms. Notably, inside-out current recordings have indicated that MS channel activity in leukaemia cells was not inhibited by internal $\mathrm{Mg}^{2+}$ [15] in distinction from $\mathrm{Mg}^{2+}$-inhibited TRP (TRPM7) channels or so-called MIC channels [11, 36]. $\mathrm{Mg}^{2+}$ effects on MS channels can be exploited as a fingerprint to search for molecular correlates of stretchactivated channels in mammalian cells [37]. 


\section{Acknowledgments}

We thank Dr JL Medina for reading the manuscript. This work was supported by the grants from Russian Foundation for Basic Research (05-04-48209 and 04-04-49630), Molecular and Cell Biology Program of the Russian Academy of Sciences.

\section{References}

1 Günther T, Vormann J. Characterization of $\mathrm{Na}^{+}$-independent $\mathrm{Mg}^{2+}$ efflux from erythrocytes. FEBS Lett 1990; 271:149-151.

2 Flatman PW. Mechanisms of magnesium transport. Annu Rev Physiol 1991; 53:259-271.

3 Romani AM, Scarpa A. Regulation of cellular magnesium. Front Biosci 2000; 5:D720-734.

4 Preston RR. A magnesium current in Paramecium. Science 1990; 250:285-288.

5 Preston RR. Transmembrane $\mathrm{Mg}^{2+}$ currents and intracellular free $\mathrm{Mg}^{2+}$ concentration in Paramecium tetraurelia. $\mathrm{J}$ Membr Biol 1998; 164:11-24.

6 Pottosin II, Schönknecht G. Ion channel permeable for divalent and monovalent cations in native spinach thylakoid membranes. J Membr Biol 1996; 152:223-233.

7 Quamme GA, de Rouffignac C. Epithelial magnesium transport and regulation by the kidney. Front Biosci 2000; 5:D694-711.

8 Zhang A, Altura BT, Altura BM. Elevation of extracellular magnesium rapidly raises intracellular free $\mathrm{Mg}^{2+}$ in human aortic endothelial cells: is extracellular $\mathrm{Mg}^{2+}$ a regulatory cation? Front Biosci 1997; 2:a13-17.

9 Maier JA, Bernardini D, Rayssiguier Y, Mazur A. High concentrations of magnesium modulate vascular endothelial cell behaviour in vitro. Biochim Biophys Acta 2004; 1689:6-12.

10 Vink R, Cernak I. Regulation of intracellular free magnesium in central nervous system injury. Front Biosci 2000; 5:D656-665.

11 Nadler MJ, Hermosura MC, Inabe K, et al. LTRPC7 is a Mg ATP-regulated divalent cation channel required for cell viability. Nature 2001; 411:590-595.

12 Schmitz C, Perraud AL, Johnson CO, et al. Regulation of vertebrate cellular $\mathrm{Mg}^{2+}$ homeostasis by TRPM7. Cell 2003; 114:191-200.

13 Konrad M, Schlingmann KP, Gudermann T. Insights into the molecular nature of magnesium homeostasis. Am J Physiol Renal Physiol 2004; 286:F599-F605.

14 Voets T, Nilius B, Hoefs S, et al. TRPM6 forms the $\mathrm{Mg}^{2+}$ influx channel involved in intestinal and renal $\mathrm{Mg}^{2+}$ absorption. J Biol Chem 2004; 279:19-25.

15 Staruschenko AV, Vedernikova EA. Mechanosensitive cation channels in human leukemia cells: calcium permeation and blocking effect. J Physiol 2002; 541:81-90.

16 Hamill OP, Marty A, Neher E, et al. Improved patch-clamp techniques for high-resolution current recording from cells and cell-free membrane patches. Pflügers Arch 1981; 391:85-100.

17 Shumilina EV, Negulyaev YA, Morachevskaya EA, et al. Regulation of sodium channel activity by capping of actin filaments. Mol Biol Cell 2003; 14:1709-1716.

18 Hille B. Ionic Channels of Excitable Membranes. Sunderland, MA, USA: Sinauer Associates, 2001.
19 Staruschenko A, Negulyaev YA, Morachevskaya EA. Actin cytoskeleton disassembly affects conductive properties of stretchactivated cation channels in leukaemia cells. Biochim Biophys Acta 2005; 1669:53-60.

20 Small DL, Morris CE. Pore properties of Lymnaea Stagnalis neuron stretch-activated $\mathrm{K}^{+}$channels. J Exp Biol 1995; 198:19191929.

21 Maingret F, Honore E, Lazdunski M, Patel AJ. Molecular basis of the voltage-dependent gating of TREK-1, a mechano-sensitive $\mathrm{K}^{+}$ channel. Biochem Biophys Res Commun 2002; 292:339-346.

$22 \mathrm{Wu} \mathrm{G}, \mathrm{McBride} \mathrm{Jr} \mathrm{DW}$, Hamill OP. $\mathrm{Mg}^{2+}$ block and inward rectification of mechanosensitive channels in Xenopus oocytes. Pflügers Arch 1998; 435:572-574.

23 Rodriguez-Contreras A, Nonner W, Yamoah EN. $\mathrm{Ca}^{2+}$ transport properties and determinants of anomalous mole fraction effects of single voltage-gated $\mathrm{Ca}^{2+}$ channels in hair cells from bullfrog saccule. J Physiol 2002; 538:729-745.

24 Narita K, Kawasaki F, Kita H. Mn and Mg influxes through Ca channels of motor nerve terminals are prevented by verapamil in frogs. Brain Res 1990; 510:289-295.

25 Kawa K. ADP-induced rapid inward currents through $\mathrm{Ca}^{2+}$. permeable cation channels in mouse, rat and guinea-pig megakaryocytes: a patch-clamp study. J Physiol 1996; 495:339-352.

26 Tinker A, Williams AJ. Divalent cation conduction in the ryanodine receptor channel of sheep cardiac muscle sarcoplasmic reticulum. J Gen Physiol 1992; 100:479-493.

27 Bezprozvanny I, Ehrlich BE. Inositol $(1,4,5)$-trisphosphate $\left(\mathrm{Ins}_{3}\right.$ )-gated $\mathrm{Ca}$ channels from cerebellum: conduction properties for divalent cations and regulation by intraluminal calcium. J Gen Physiol 1994; 104:821-856.

28 Kaestner L, Christophersen P, Bernhardt I, Bennekou P. The non-selective voltage-activated cation channel in the human red blood cell membrane: reconciliation between two conflicting reports and further characterization. Bioelectrochemistry 2000; 52:117-125.

29 Monteilh-Zoller MK, Hermosura MC, Nadler MJ, et al. TRPM7 provides an ion channel mechanism for cellular entry of trace metal ions. J Gen Physiol 2003; 121:49-60.

30 Nilius B, Watanabe H, Vriens J. The TRPV4 channel: structurefunction relationship and promiscuous gating behaviour. Pflügers Arch 2003; 446:298-303.

31 Alessandri-Haber N, Yeh JJ, Boyd AE, et al. Hypotonicity induces TRPV4-mediated nociception in rat. Neuron 2003; 39:497-511.

32 Sachs F, Morris CE. Mechanosensitive ion channels in nonspecialized cells. Rev Physiol Biochem Pharmacol 1998; 132:1-77.

33 Hamill OP, Martinac B. Molecular basis of mechanotransduction in living cells. Physiol Rev 2001; 81:685-740.

34 Zou H, Lifshitz LM, Tuft RA, Fogarty KE, Singer JJ. Visualization of $\mathrm{Ca}^{2+}$ entry through single stretch-activated cation channels. Proc Natl Acad Sci USA 2002; 99:6404-6409.

35 Mozhayeva GN, Naumov AP. The permeability of sodium channels to hydrogen ions in nerve fibres. Pflügers Arch 1983; 396:163-173.

36 Clapham DE. Sorting out MIC, TRP, and CRAC ion channels. J Gen Physiol 2002; 120:217-220.

37 Maroto R, Raso A, Wood TG, et al. TRPC1 forms the stretchactivated cation channel in vertebrate cells. Nat Cell Biol 2005; 7:179-186. 